\title{
MENINGKATKAN HASIL BELAJAR SISWA DENGAN MODEL PEMBELAJARAN QUESTIONING TEKNIK CARD SORT KELAS V SD NEGERI 168234 TEBING TINGGI
}

\author{
Rosminem Wardiyaningsih
}

Surel: rosminemjawa@gmail.com

\begin{abstract}
ABSTRAK
Penelitian ini bertujuan untuk meningkatkan hasil belajar siswa mata pelajaran PKn melalui model questioning teknik card sort. Penelitian tindakan kelas ini dilaksanakan sebanyak 2 siklus dengan empat tahapan yaitu : perencanaan, pelaksanaan, observasi, refleksi. Subjek penelitian ini adalah siswa kelas V SD Negeri 168234 Tebing Tinggi sebanyak 33 siswa.Penelitian ini menggunakan teknik analisis dekriptif kualitatif. Pembelajaran PKn menggunakan model questioning teknik card sort dapat meningkatkan hasil belajar siswa kelas V SD Negeri 168234 Tebing Tinggi.
\end{abstract}

Kata Kunci : Hasil Belajar, Model Pembelajaran Questioning, Card-Sort

\section{PENDAHULUAN}

Pendidikan Kewarganegaraan merupakan mata pelajaran wajib pada semua satuan pendidikan dasar dan pendidikan menengah. Aspek-aspek yang menjadi lingkup mata pelajaran ini, mencakup persatuan dan kesatuan bangsa, norma hukum dan peraturan, hak asasi manusia, kebutuhan warga negara, kekuasaan dan politik, pancasila, dan globalisasi (Depdiknas, 2007). Menurut Aryani dan Susantim (2010:18), kewarganegaraan merupakan materi yang memfokuskan pada pembentukan diri yang beragam, baik dari segi agama, sosio-kultural, bahasa, usia, dan suku bangsa, untuk menjadi warga negara Indonesia yang cerdas, terampil, dan berkarakter.

Melalui mata pelajaran PKn ini, diharapkan siswa sebagai warga negara dapat mengkaji dan memahami hak, kewajiban dan tanggung jawabnya sebagai warga negara. Berkaitan dengan tujuan pendidikan nasional, pembangunan dalam dunia pendidikan perlu ditingkatkan. Melalui pembelajaran PKn akan ditanamkan moral yang baik pada diri siswa dari sejak dini. Namun kenyataannya, sebagian siswa memandang mata pelajaran Pendidikan Kewarganegaraan sebagai mata pelajaran yang bersifat konseptual dan teoritis. Akibatnya siswa ketika mengikuti pembelajaran PKn merasa cukup mencatat dan menghafalkonsep-konsep dan teoriteori yang dijelaskan oleh guru, tugas-tugas terstruktur yang diberikan dikerjakan secara tidak serius dan bila dikerjakan pun sekedar memenuhi formalitas.

Kegiatan belajar akan aktif apabila peserta didik melakukan 
kegiatan belajar yang harus dilakukan. Mereka menggunakan otak-otak mereka untuk mempelajari gagasan-gagasan memecahkan berbagai masalah dan menerapkan apa yang mereka pelajari. Dalam kegiatan pembelajaran sebaiknya siswa diberi kesempatan untuk berdiskusi dan berpendapat. Menurut Silbermen, "tanpa peluang untuk mendiskusikan, mengajukan pertanyaan, mempraktikkan, dan mengajarkan kepada siswa lain, proses belajar yang sesungguhnya tidak akan terjadi (Silbermen, 2006 : 27). Hal ini dimaksudkan untuk menjaga perhatian siswa selama proses belajar terjadi.

Hasil observasi terhadap guru, siswa, dan media atau alat pembelajaran. Selain itu, juga diperoleh dari hasil wawancara dan catatan lapangan. Berdasarkan refleksi awal ditemui data sebagai berikut. Kenyataannya dari hasil belajar dan observasi di SD Negeri 168234 Tebing Tinggi pada siswa kelas $\mathrm{V}$, pembelajaran $\mathrm{Pkn}$ dilaksanakan dengan metode ceramah. Akibatnya, siswa menjadi pasif dan hasil belajar siswa rendah. Hasil belajar siswa yang tuntas belajar pada semester sebelumnya hanya 22 siswa $(66,66 \%)$ dan 11 siswa belum tuntas belajar $(33,34 \%)$, dengan nilai tertinggi 90 dan nilai terendah 60 .

Untuk meningkatkan mutu pendidikan dan pengajaran salah satunya adalah dengan memilih strategi atau cara dalam menyampaikan materi pelajaran agar diperoleh peningkatan hasil belajar siswa khususnya pelajaran Pkn. Misalnya dengan membimbing siswa untuk bersama-sama terlibat aktif dalam proses pembelajaran dan mampu membantu siswa berkembang sesuai dengan taraf intelektualnya akan lebih menguatkan pemahaman siswa terhadap konsep-konsep yang diajarkan.

Salah satu model pembelajaran yang dapat diterapkan adalah model pembelajaran questioning teknik card sort. Bertanya (questioning) dapat dipandang sebagai refleksi dari keingintahuan setiap individu, sedangkan menjawab pertanyaan mencerminkan kemampuan seseorang dalam berpikir. Suhito (dalam Ribowo, 2006:6), "Bertanya merupakan rasa ingin tahu akan jawaban yang tidak (belum) diketahuinya. Rasa ingin tahu merupakan dorongan atau rangsangan yang efektif untuk belajar dan menantang untuk memberi jawaban".

Teknik card sort adalah Strategi Card Sort merupakan salah satu dari beberapa strategi yang digunakan untuk mengaplikasikan pembelajaran aktif. Menurut Zaini(2002) bahwa Card Sort merupakankegiatan kolaboratif yang bisa gigunakan untuk mengajarkan konsep, karakteristik klasifikasi, fakta tentang obyek atau mereview informasi. Gerakan fisik yang 
dominan dalam strategi ini dapat membantu mendinamiskan kelas yang jenuh atau bosan.

Strategi Card Sort merupakan salah satu dari beberapa strategi yang digunakan untuk mengaplikasikan pembelajaran aktif atau Active Learning (Silberman, 2006: 10). CardSort adalah rencana yang cermat untuk mencapai sasaran dalam kegiatan belajar mengajar dengan kegiatan kolaboratif yang bisa digunakan untuk mengajarkan konsep, karakteristik, penggolongan sifat, fakta tentang objek atau mereview informasi. Gerakan yang dominan dalam dalam strategi ini dapat membantu mendinamisir kelas yang jenuh dan bosan (Zaini, 2008:53).

Ciri khas dari pembelajaran aktif model Card Sort ini adalah siswa mencari bahan sendiri atau materi yang sesuai dengan kategori kelompok yang diperolehnya dan siswa mengelompok sesuai kartu indeks yang diperolehnya.Menurut Zaini (2002:51) ada beberapa kelebihan metode card sort antara lain sebagai berikutSiswa berperan secara aktif dalam proses pembelajaran, Penilaiankepada siswa dilakukan secara otentik, membantu siswa berpikir untuk kritis, Sosialisasi antara siswa lebih terbangun. Sedangkan kelemahannya adalah Metode ini hanya terpaku pada satu media pembelajaran, Membutuhkan ruangan yang agak luas untuk tempat bergerak siswa.
Penelitian Fitrianie (2010) menyimpulkan bahwa penerapan metode permainan Card Sort dapat meningkatkan perhatian siswa dalam mata materi Aqidah Akhlak dengan sub materi Sifat Wajib Allah SWT di SDN Pringapus 02 tahun ajaran 2009/2010. Hal ini dapat diketahui dari peningkatan perhatian yang terjadi dari siklus I dengan presentase $47,6 \%$ naik menjadi $64,5 \%$ pada siklus II. Dan pada siklus III naik lagi menjadi $70,9 \%$.

Berdasarkan uraian pada latar belakang masalah, maka dapat dirumuskan permasalahan: "Apakah dengan menggunakan model pembelajaran questioning teknik card sort meningkatkan hasil belajar PKn siswa kelas V SD Negeri 168234 Tebing Tinggi Tahun pelajaran 2015/2016?". Tujuan dari penelitian ini adalah untuk meningkatkan hasilbelajar Pkn siswa kelas V SDNegeri 168234 Tebing Tinggi tahun pembelajaran 2015/2016 melalui model pembelajaran questioning teknik card sort.

\section{METODE PENELITIAN}

Dalam penelitian ini, peneliti menggunakan metode deskriptif.Metode deskriptif adalah suatu metode penelitian yang ditujukan untuk menggambarkan fenomena-fenomena yang ada, yang berlangsung pada saat ini, atau saat yang lampau. Adapun subjek penelitian adalah siswa kelas II SD Negeri 168234 Tebing Tinggi 
semester 2 tahun pelajaran 2015/2016 dan sumber data yang digunakan adalah siswa dan teman sejawat.

Pada Penelitian tindakan kelas data yang dikumpulkan dapat berbentuk kuantitatif maupun kualitatif. Penelitian tindakan kelas tidak menggunakan uji statistik, tetapi dengan deskriptif. Data kuantitatif yang berupa nilai dianalisis dengan menggunakan analisis deskriptif komparatif yaiu membandingkan nilai tes kondisi awal, nilai tes setelah siklus I, dan II yaitu nilai dari hasil ulangan harian siswa kelas II pada siklus I dan II. Komponen pengajaran model questioning teknik card sortyang sangat data kualitatif yang berupa observasi kegiatan guru, dan sisa serta data kuantitatif yangberupa nilai hasil ulangan harian siswa kelas II. Prosedur penelitian tindakan kelas iniada tahap perencanaan tindakan, pelaksanaan tindakan, pengamatan dan evaluasi, dan refleksi.

Masing-masing siklus terdiri dari dua kali pertemuan yaitu sebagai berikut;

Sebelum mengadakan penelitian peneliti menyusun rumusan masalah, tujuan dan membuat rencana tindakan, termasuk di dalamnya instrumen penelitian dan perangkat pembelajaran.

Suatu tindakan ke dalam konteks proses belajar mengajar yang sebenarnya. Implementasi tindakan dimulai saat sebelum kegiatan dengan persiapan sebelum kegiatan dimulai, yaitu saat guru mengkondisikan siswa agar siap mengikuti pembelajaran.

Menjelasksan materi secara garis besar untuk merangsang keaktifan siswa sesuai dengan RPP. Peneliti mengatur pelaksanaan penelitian pada proses belajar mengajar dan memberi rangsangan untuk membangkitkan motivasi, keaktifan, dan perhatian siswa pada materi pelajaran. Guru emberikan penjelasan cara permainan card sort kepada siswa. Peneliti membagi siswa menjadi kelompok-kelompok perbangku. Peneliti memberikan kartu dengan arti semboyan bhineka tunggal ika, mengapa Indonesia berbentuk kesatuan, fungsi pancasila bagi NKRI. Peneliti menyuruh mencocokkan dan menempelkan hasilnya di papan secara urut, Peneliti meminta salah satu dari anggota kelompok untuk menjelaskan hasil sortir kartunya, kemudian meminta komentar dari kelompok lain. Setelah itu guru menyimpukan pelajaran dan menutup pelajaran dengan tes ulangan harian.

Pada siklus II ini kegiatannya hampir sama dengan siklus I namun kekurangan yang terjadi pada siklus I diperbaiki pada siklus II. Kegiatan awal yang dilakukan pada tahapan ini adalah guru memberikan apersepsi, guru memberikan pengarahan tentang topik yang akan dipelajari. Peneliti mengatur pelaksanaan penelitian pada proses belajar mengajar dan memberi rangsangan untuk membangkitkan motivasi, keaktifan, dan perhatian 
siswa pada materi pelajaran. Peneliti memberikan kartu dengan pertanyaan makna kesatuan Indonesia dari segi ekonomi dan sosial budaya. Peneliti menyuruh mencocokkan dan menempelkan hasilnya di papan secara urut. Hal-hal yang dianggap kurang pada siklus I diperbaiki pada siklus II.

Pengamatan dilakukan peneliti sendiri dan dibantu oleh pengamat.Pelaksanaan observasi dilakukan pada saat proses pembelajaran berlangsung dengan berpedoman pada lembar observasi yang telah dibuat oleh peneliti.

Data yang diperoleh pada lembar observasi, dianalisis secara lebih dalam dan tajam pada siklus ke dua ini. Kemudian dilakukan refleksiatau perenungan. Pelaksanaan refleksi merupakan hasil observasi atau pengamatan peneliti pada saat melakukan observasi di kelas dan lingkungan sekolah yang bertujuan untuk mengevaluasi hasil tindakan yang telah dilakukan yaitu dengan menerapkan model pembelajaran questioning teknik card sort. Tahapan ini dilakukan secara berkesimbungan sehingga ditemukan hasil yang optimal.

Instrumen yang digunakan dalam penelitian ini adalah pedoman observasi, test hasil belajar dan kegiatan belajar mengajar. Data aktivitas belajar dan kendala yang dihadapi selama proses pembelajaran dikumpulkan melalui observasi (lembar observasi terlampir). Data hasil observasi, dan data hasil wawancara yang jenis datanya berupa pernyataan-pernyataan, dianalisis dengan menggunakan teknik analisis statistik deskriptif.

Metode pengumpulan data penelitian ini adalah tertulis dan observasi. Penelitian ini dikatakan berhasil apabila siswa telah memperoleh nilai ketuntasan secara klasikal minimal $85 \%$ dari jumlah siswa dengan rumus sebagai berikut :

Persentase Ketuntasan klasikal $=$ $\underline{\text { Jumlah siswa yang tuntas }} \times 100$ $\%$

Jumlah siswa yang mengikuti tes

\section{HASIL DAN PEMBAHASAN}

Hasil data penelitian diuraikan berdasarkan siklus-siklus tindakan pembelajaran. Hasil data tersebut disesuaikan dengan masalah penelitian mencakup data perencanaan, dan proses pembelajaran. Hasil penelitian tindakan kelas menunjukkan bahwa pengamatan yang dilakukan oleh mitra kolaborasi dan peneliti pada aktivitas guru dan siswa melalui penerapan model pembelajaran questioning teknik card sort pada mata pelajaran PKn kelas V SD Negeri 168234 Tebing Tinggi dapat dilihat pada Tabel 1 yaitu sebagai berikut : 


\begin{tabular}{|c|c|c|c|}
\hline \multirow{2}{*}{ Keterangan } & \multicolumn{3}{|c|}{ Peningkatan Hasil Belajar } \\
\cline { 2 - 4 } & $\begin{array}{c}\text { Pra } \\
\text { siklus }\end{array}$ & Sikus I & Siklus II \\
\hline $\begin{array}{c}\text { Nilai X- } \\
\text { ulangan } \\
\text { harian }\end{array}$ & 70,5 & 72,16 & 73,43 \\
\hline $\begin{array}{c}\text { Jumlah } \\
\text { Siswa }\end{array}$ & 22 & 26 & 31 \\
\hline $\begin{array}{c}\text { Persentase } \\
\text { Aktivitas } \\
\text { Siswa (\%) }\end{array}$ & 71 & 76,7 & 80,6 \\
\hline $\begin{array}{c}\text { Persen } \\
\text { Ketuntasan } \\
(\%)\end{array}$ & 66,66 & 78,78 & 93,93 \\
\hline
\end{tabular}

Hasil analisis pengamatan peneliti dari tindakan pra siklus, siklus I dan siklus II pada Tabel 1 terjadi peningkatan hasil belajar siswa. Hal ini dapat dilihat dengan peningkatan jumlah siswa dari 22 siswa yang tuntas belajar pada pra siklus menjadi 31 siswa yang tuntas belajar model pembelajaran questioning teknik card sort pada siswa kelas V SD Negeri 168234 Tebing Tinggi. Pada pra tindakan dari 22 siswa dalam satu kelas, terdapat 11 siswa yang belum mencapai KKM.

Tindakan siklus I dengan menggunakan model pembelajaran questioning teknik card sort, pada pokok bahasan pentingnya keutuhan Negara Kesatuan Republik Indonesia (NKRI). Selama pembelajaran berlangsung, guru kelas selaku mitra kolaborasi melakukan pengamatan tentang kegiatan pembelajaran yang dilakukan dan keterampilan siswa dalam bertanya. Nilai rata-rata kelas pembelajaran siklus I menunjukkan peningkatan bila dibanding dengan pra tindakan ke siklus I, yaitu dari 70,5 menjadi 72,16 . Nilai maksimal 90 dan nilai minimal 64. Sementara persentase ketuntasan belajar siswa yang telah mencapai KKM dari pra tindakan meningkat dari $66,66 \%$ menjadi $78,78 \%$ pada siklus I.

Hal-hal yang dianggap kurang pada siklus I seperti perlu adanya dialog yang lebih santai agar siswa lebih terbuka dan tidak sungkan dalam mengeluarkan pendapat, memberikan motivasi pada siswa serta pengoptimalan belajar diperbaiki pada siklus II. Pada siklus II meningkat menjadi $93,93 \%$. Terjadi peningkatan $15,15 \%$ dari siklus I.setelah mendapatkan metode pembelajaran model pembelajaran questioning teknik card sort. Pada siklus II hanya 2 (empat) siswa yang belum memenuhi KKM atau 31 $(98,98 \%)$ siswa sudah tuntas belajar. Pada siklus II siswa sudah terlihat terdapat peningkatan keaktifan dan ketepatan dalam menemukan pasangan jawaban yang tepat.

Pembelajaran adalah kegiatan guru terprogram dalam desain instruksional, untuk membuat siswa belajar secara aktif, yang menekan pada penyediaan sumber belajar (Dimyati dan Mudjiono, 206 : 297). Proses pembelajaran dengan menggunakan model pembelajaran questioning teknik card sort pada penelitian ini dapat meningkatkan hasil belajar siswa. Mata pelajaran Pkn yang diajarkan kepada siswa 
adalah adanya proses keterlibatan seluruh atau sebagian besar potensi diri siswa (fisik dan nonfisik) yang memberikan makna bagi diri dan kehidupannya saat ini hingga di masa yang akan datang (life skill) (Kunandar, 2007 : 287).

Pada siklus I hasil belajar belum bisa dikatakan berhasil karena belum memenuhi kriteria ketuntasan. Hal tersebut dikarenakan pada saat pelaksanaan pembelajaran ada beberapa siswa yang pasif, karena Banyak siswa ragu - ragu dan kurang percaya diri untuk bertanya, memberi pendapat, dan menjawab pertanyaan. Selain itu Suasana kelas ramai dan banyak siswa yang tidak memperhatikan penjelasan guru maupun memperhatikan teman atau siswa lain yang mengeluarkan pendapat.Hasil refleksi yaitu berupa temuaan tingkat keefektifan desain pembelajaran dengan menggunakan model pembelajaran questioning teknik card sort dengan penjelasan awal di kelas sebelum observasi dengan jelas dan pendampingan yang maksimal dalam kegiatan - kegiatan siswa dan daftar permasalahan yang muncul dilapangan dituangkan kembali kedalam rancangan tindakan berikutnya,selanjutnya tindakan refleksi terhadap rancangan yang telah disusun kembali sebelum digunakan.

Siklus II ditujukan untuk memperbaiki kekurangan yang terjadi pada siklus I berdasarkan hasil refleksi siklus I. Dalam perbaikan ini diharapkan siswa menjadi lebih aktif dalam proses pembelajaran dan hasil belajar siswa dapat meningkat sesuai target yang akan dicapai. Pada siklus II ini ada peningkatan dan ketertarikan siswa untuk belajar Pkn sehingga prosespembelajaran berlangsung baik dan menyenangkan. Siswa sudah terlihat terdapat peningkatan keaktifan danketepatan dalam menemukan pasangan jawaban yang tepat.

Dengan melihat indikator yangt telah ditetapkan sebelumnya, hasil yang diperoleh telah mencapai lebih dari batas minimal indikator keberhasilan sehingga penelitian tidak perlu dilanjutkan lagi untuk siklus berikutnya. Oleh karena itu dapat disimpulkan bahwa proses pembelajaran dengan penerapan model pembelajaran questioning teknik card sort sangat sesuai dengan mata pelajaran Pkn, maka Penelitian Tindakan Kelas (PTK) ini bisa dikatakan berhasil karena hasil peningkatan proses pembelajarannya optimal.

Siklus II mengalami perubahan dari aspek kognitif dan aspek afektif. Pelaksanaan tindakan kelas pada siklus II berjalan dengan baik dan lancar. Siswa sudah menunjukkan keaktifannyadalam pembelajaran. Dapat dikatakan bahwa penggunaan teknik card sort melibatkan pembelajaran aktif pada siswa. Hal ini sesuai dengan pendapat Silberman (2006: 10), strategi card sort merupakan salah satu dari 
beberapa strategi yang digunakan untuk mengaplikasikan pembelajaran aktif atau Active Learning.

Kelebihan dari model pembelajaran questioning teknik card sort yaitu menjadi pembelajaran menyenangkan dan siswa tidak merasa bosan. Dapat mengaktifkan siswa dalam hal bertanya, menjawab pertanyaan maupun menyampaikan pendapat. Hasil belajar siswa mengalami peningkatan, ini terlihat pada hasil nilai setiap siklus makin meningkat. Hal ini sesuai pendapat Hisyam Zaini (2002: 51) ada beberapa kelebihan metode card sort antara lain sebagai berikut; siswa berperan secara aktif dalam proses pembelajaran, penilaiankepada siswa dilakukan secara otentik, membantu siswa berpikir untuk kritis, dan sosialisasi antara siswa lebih terbangun.

Siswa merasa lebih cepat mengerti dengan pendekatan pembelajaran yang digunakan. Maka dari itu model questioning teknik card sortterbukti meningkatkan hasil belajar siswa, terlihat dari hasil persentase ketuntasan belajar siswa yang mengalami peningkatan cukup drastis mulai dari pre test, siklus I hingga siklus II. Maka dari itu berdasarkan hasil temuan dan analisis data penelitian maka dapat disimpulkan bahwa penggunaan model pembelajaran questioning teknik card sort dapat meningkatkan hasil belajar siswa kelas V SD Negeri 168234 Tebing Tinggi.

\section{SIMPULAN}

Kesimpulan dari hasil penelitian diatas adalah penggunaan model pembelajaran questioning teknik card sort mata pelajaran Pkn di kelas V SD Negeri 168234 Tebing Tinggi tahun pelajaran 2015/2016 berdampak positif dalam meningkatkan aktivitas dan hasil belajar siswa setiap siklusnya. Hal tersebut dapat dilihat dari peningkatan persentase ketuntasan belajar siswa pada siklus I (78,78\%), siklus II $(93,93 \%)$.

Dari hasil penelitian yang diperoleh beberapa saran agar proses belajar mengajar tematik lebih efektif dan memberikan hasil yang optimal bagi siswa yaitu :

a. Hendaknya kepala sekolah mengikut sertakan guru-guru dalam pelatihan-pelatihan atau seminar-seminar agar guru lebih terampil menggunakan berbagai metode terutama menggunakan metode pembelajaran aktif seperti questioning teknik card sort.

b. Disini guru dituntut untuk lebih kreatif dalam memvariasikan model pembelajaran, membimbing siswa untuk lebih aktif dalam memberikan umpan balik, membangkitkan minat belajar dan rasa ingin tahu, serta mengarahkan siswa untuk lebih aktif dalam pembelajaran penemuan dan berdiskusi.

c. Siswalebih giat dalam belajar dan tidak malu atau takut bertanya kepada guru tentang materi yang 
Rosminem Wardiyaningsih: Meningkatkan Hasil ...

masih kurang dipahami atau kurang jelas, dan disarankan untuk dapat menghargai pertanyaan atau jawaban yang diajukan teman.

\section{DAFTAR RUJUKAN}

Aryani, dkk. 2010. Pendidikan Kewarganegaraan Berbasis Nilai. Bogor: Ghalia Indonesia.

Dimyati Dan Mujiono. 2006. Belajar dan Pembelajaran. Jakarta: Rineka Cipta.

Fitrianie, W. 2010. Penerapan Metode Permainan Card Sort Untuk Meningkatkan Pemahaman Materi Aqidah Akhlak Pada Siswa Kelas III SDN Pringapus 02 Tahun Ajaran 2009/2010. Skripsi. Salatiga: STAIN.

Kunandar. 2007. Guru Profesional (Implementasi KTSP dan Sukses dalam Sertifikasi Guru). Jakarta : Rajawali Press.

Silbermen, Melvin. 2006. Active Learning : 101 Cara Belajar Siswa Aktif. Bandung: Nusamedia.

Zaini, Hisyam. 2002. Strategi Pembelajaran Aktif di Perguran Tinggi.Yogyakarta: CTSD. 